\title{
Selectivity of geraniol synthase in aromatic species to control of cotton ramulosis
}

\author{
Kaliny V.P. Silva ${ }^{1}$, Yrlânia L. Guerra ${ }^{1}$, Gerckson M.R. Alves ${ }^{2}$, Péricles A. Melo-Filho ${ }^{1}$, Liziane M. Lima ${ }^{3 *}$, \\ and Roseane C. Santos ${ }^{3}$ \\ ${ }^{1}$ Universidade Federal Rural de Pernambuco, Rua Dom Manuel de Medeiros, S/N, Dois Irmãos, CEP 52171-900, Recife, Pernambuco, \\ Brasil. \\ ${ }^{2}$ Universidade Estadual da Paraíba, Rua Baraúnas, 351-Universitário, CEP 58429-500, Campina Grande, Paraíba, Brasil. \\ ${ }^{3}$ Embrapa Algodão, Rua Osvaldo Cruz, 1143, Centenário, CEP 58428-095, Campina Grande, Paraíba, Brasil. \\ *Corresponding author (liziane.lima@embrapa.br).
}

Received: 15 December 2017, Accepted: 3 April 2018; doi:10.4067/S0718-58392018000200287

\begin{abstract}
Ramulosis (Colletotrichum gossypii South var. cephalosporioides Costa) is a fungal disease of cotton (Gossypium hirsutum L.) that causes damage to leaves, stems, and bolls by reducing fiber production; it can be controlled by chemical fungicides. Geraniol is a monoterpenoid produced by some aromatic plant species whose fungicidal properties have been widely reported. Geraniol synthase (GES; EC 3.1.7.11) is the precursor enzyme involved in the biosynthetic chain of geraniol. Geraniol synthase (ges) gene transcripts were prospected in 11 aromatic species with molecular and phytopathological tools to identify promising accessions for further use in in vitro and in vivo assays involving the control of cotton ramulosis. Mentha pulegium L. oil highly expressed ges and inhibited fungal growth at $1000 \mu \mathrm{LL}^{-1}$ in an in vitro assay. Validation assays were carried out in two environments and M.pulegium at $2000 \mu \mathrm{L} \mathrm{L}^{-1}$ reduced the initial and final severity indices of the disease to $48 \%$ and $52 \%$, respectively, in preventive treatments; in curative assays, indices were $44 \%$ and $54 \%$, respectively. This indicates that it is a promising bioactive compound to control cotton ramulosis.
\end{abstract}

Key words: Colletotrichum gossypii, Gossypium hirsutum, essential oil, fungi, monoterpene, secondary metabolites.

\section{INTRODUCTION}

Increased crop yield associated with low management costs have been a major challenge for agricultural competitiveness in any country of the world. Chemical pesticides represent high crop management costs in addition to some negative effects to the environment.

Brazil is a large producer of fibrous and oleaginous crops and great consumer of pesticides for crop protection (Pignati et al., 2014). Herbicide costs represent approximately $45 \%$ of total commercial pesticides, while fungicides and insecticides contribute $14 \%$ and $12 \%$, respectively (Anvisa, 2014). The use of plant bioactive compounds represents an alternative pest control method because it minimizes these costs: their efficiency and viability have been reported in several studies in the literature (Melo et al., 2013; Singh et al., 2014; Guerra et al., 2015).

Aromatic species offer extensive benefits for crop pest control due to biopesticide activity, mainly by essential oils (Hussain et al., 2008; Lima et al., 2008). These oils mainly consist of terpenes and terpenoids (geraniol, sabinene, thymol, carvacrol, and eugenol among others), which are volatile molecules with low molecular weight that are structurally different. They accumulate in all organs and exhibit several functions depending on the oil's main bioactive compounds, including germination inhibitors, fungicides, pollinator-attracting compounds, and insecticides (Lima et al., 2008; Melo et al., 2013; O’Bryan et al., 2015). 
Geraniol is a cyclic monoterpenoid alcohol present in several aromatic species, mainly in flowers (Guerra et al., 2015). The products of geraniol oxidation, geranial and neral, produce citral, which is a citrus odor compound abundant in several genera such as Cymbopogon, Zingiber, Ocimum, Mentha, Origanum, and Rosmarinus (Hussain et al., 2008; Karray-Bouraoui et al., 2009; Guerra et al., 2015). Geraniol oil has been reported to be effective against plant pathogens, and it has potent fungicidal and bactericidal activity (Guerra et al., 2015).

The geraniol precursor enzyme is encoded by geraniol synthase (ges), a gene with an open reading frame (ORF) ranging from 1.7 to $2.0 \mathrm{~kb}$. The National Center for Biotechnology Information (NCBI) gene bank provides the ges sequences of Cinnamomum tenuipilum (Yang et al., 2005), Olea europaea (Vezzaro et al., 2012), Catharanthus roseus (Simkin et al., 2013), Perilla setoyensis (Masumoto et al., 2010), Ocimum basilicum (Iijima et al., 2004), Phyla dulcis (Yang et al., 2011), and Vitis vinifera (Martin et al., 2010). The alignment of these sequences shows several homologous regions, which can be used as specific probes or tags to assist in molecular studies related to crop protection.

Cotton (Gossypium hirsutum L.) is an important commodity in the world economy. The crop is grown in several countries and provides natural fibers to the textile industry. Brazil is a large cotton producer with over 1.4 million tons on 957000 ha (Conab, 2016). The high cost to protect crops against pests is the limiting factor in cotton management, especially fungal diseases that occur in the entire Brazilian cotton belt.

Ramulosis (Colletotrichum gossypii South var. cephalosporioides Coast) is a serious fungal disease in cotton fields that causes certain damage and depends on the infestation level (Suassuna and Coutinho, 2015). Strong shedding takes place when the disease is established before blooming, and this affects plant growth and boll production (Melo et al., 2013). The disease is controlled by massive applications of chemical fungicides. The literature provides some research results showing the control of Colletotrichum by essential oils, although most of them are limited to in vitro assays. Rozwalka et al. (2008) reported antifungal activity with lemongrass oil (Cymbopogon citratus [DC.] Stapf) against Glomerella cingulata and Colletotrichum gloeosporioides on fruit guava. Sousa Júnior et al. (2009) tested several essential oils against $C$. gloeosporioides on passion fruit (Passiflora edulis Sims) and found total inhibition with Ocimum gratissimum L., Lippia sidoides Cham., L. citrodora Kunth, and C. citratus oils at $1 \mu \mathrm{L} \mathrm{mL}^{-1}$ in in vitro assays.

Using C. gossypii var. cephalosporioides, Lima et al. (2008) showed that citronella (Cymbopogon nardus) oil inhibited mycelial growth by approximately $94 \%$ and subsequent reduction of disease progression in a preventive assay carried out in a greenhouse. Santos et al. (2011) used Rosmarinus officinalis and Baccharis trimera oils at $1 \%$ in preventive assays and found ramulosis in cotton plants decreased to approximately $69 \%$ and 55\%, respectively. Despite the large contribution of findings available in the literature regarding pest control via plant bioactive compounds, there is limited information as to the effectiveness of control under natural conditions. This information is essential to validate the bioprocess and make further recommendations to growers. In the present study, we evaluated the effectiveness of geraniol to control cotton ramulosis, focusing on the selection of plants with high ges expression and subsequent validation of fungitoxicity through phytopathological and agronomic assays.

\section{MATERIALS AND METHODS}

\section{Germplasm and molecular procedures}

Seeds of 11 aromatic species were commercially acquired and used for bioassays. These were Cymbopogon nardus (L.) Rendle, Jasminum officinale L., Mentha pulegium L., M. viridis (L.) L., Ocimum basilicum L., O. gratissimum L., Origanum majorana L., Peumus boldus Molina, Plectranthus amboinicus (Lour.) Spreng., Rosmarinus officinalis L., and Ruta graveolens $\mathrm{L}$.

Sowing was carried out in a greenhouse using 2-L pots containing previously fertilized soil (NPK, 10:10:10, v/v, ammonium sulfate, simple superphosphate, and potassium chloride) and watered daily. After $30 \mathrm{~d}$ of emergence, young leaves $(1 \mathrm{~g})$ from each accession were collected for RNA extraction (Invisorb Spin Plant Mini Kit, Stratec Molecular, Berlin, Germany) according to the manufacturer's recommendations.

\section{Reverse transcription polymerase chain reaction (RT-PCR) semiquantitative and blotting analyses}

The cDNA of each accession was synthesized (ImProm-II Reverse Transcription System kit, Promega Corporation, Madison, Wisconsin, USA) according to the manufacturer's recommendations. Reverse transcription was performed 
in $44 \mu \mathrm{L}$ as follows: $11 \mu \mathrm{L}$ cDNA reaction containing $1 \mu \mathrm{g}$ total RNA, $0.5 \mu \mathrm{g}$ Oligo dT 15 (10 mM), $1 \mathrm{X}$ ImProm-II Reaction Buffer, $6 \mu \mathrm{L} \mathrm{MgCl}_{2}(25 \mathrm{mM}), 0.5 \mu \mathrm{L}$ dNTP set $(10 \mathrm{mM}), 1 \mathrm{U}_{\mu} \mathrm{L}^{-1}$ Recombinant RNase Ribonuclease Inhibitor, and $1.25 \mathrm{U} \mathrm{\mu L}^{-1} \mathrm{ImProm}-\mathrm{II} \mathrm{RT}$. Samples were incubated in a thermal cycler at $25^{\circ} \mathrm{C}$ for 5 min and then at $42{ }^{\circ} \mathrm{C}$ for $1 \mathrm{~h}$ and $70{ }^{\circ} \mathrm{C}$ for $15 \mathrm{~min}$.

For semiquantitative assays, reactions were performed in a $25 \mu \mathrm{L}$ final volume containing $2 \mu \mathrm{L}$ cDNA $(1 \mu \mathrm{g}), 0.04 \mathrm{U}$ Taq DNA Polymerase (Fermentas), $0.2 \mathrm{mM}$ dNTP set (10 mM), $1.5 \mu \mathrm{L} \mathrm{MgCl}_{2}(25 \mathrm{mM}), 1 \mathrm{X}$ kit buffer (10X), and 0.8 $\mu \mathrm{L}$ each of forward (5' AGGTTGGAAGCGAGACGATTC 3') and reverse (5' GTTCCBAGATCATCCCRRAG 3') ges primers $(10 \mathrm{mM})$. This primer combination amplifies a $0.52 \mathrm{~kb}$ ges fragment. The RT-PCR thermal condition was predenaturation at $95^{\circ} \mathrm{C}$ for $7 \mathrm{~min}$, followed by 35 denaturation cycles at $94{ }^{\circ} \mathrm{C}$ for $1 \mathrm{~min}$, annealing at $56^{\circ} \mathrm{C}$ for $1 \mathrm{~min}$, and extension at $72^{\circ} \mathrm{C}$ for $1 \mathrm{~min}$. A final extension was added at $94^{\circ} \mathrm{C}$ for $5 \mathrm{~min}$. The $\beta$-actin gene was selected as a reference control, which is represented by a $0.50 \mathrm{~kb}$ fragment (forward, 5' GATRTTGTCATATCTGCACTTGCA 3' and reverse, 5' GGCTCTTCTGATCATCCTCTTC 3' primers).

Amplicons were analyzed in agarose gel (0.8\%) and photo-documented (MiniBIS Pro, Bio-Imaging Systems, Neve Yamin, Israel). The gel was then used for PCR blotting using a non-radioactive probe to validate the products generated by the reaction (Soares et al., 2018). Amplicons were transferred to a nylon membrane (Hybond-N +, Amersham Pharmacia, St. Albans, UK) by capillarity. A probe ( $0.52 \mathrm{~kb}$ ) was generated with forward (5' AGGTTGGAAGCGAGACGATTC 3') and reverse (5' GTTCCBAGATCATCCCRRAG 3') ges primers (10 mM) and labeled with AlkPhos Direct and Labeling and Detection Systems kit (Amersham Pharmacia) according to the manufacturer's recommendation.

Relative expression of ges transcripts by quantitative reverse transcription polymerase chain reaction (qRT-PCR) The relative expression of ges was estimated by qRT-PCR (Eco Real-Time PCR System, Illumina, San Diego, California, USA) according to the manufacturer's instructions. Reactions were performed in a $10 \mu \mathrm{L}$ final reaction containing 5 $\mu \mathrm{L}$ Evagreen (Biotium, Fremont, California, USA), $0.8 \mu \mathrm{L}$ forward (5' GGTGGTGGAAGGATGCTCGGTTTGG 3') and reverse (5' CCATARGTATCKAAAMTATCATC 3') ges primers (10 mM), and $2 \mu \mathrm{L}$ cDNA (1:10, v/v). Two-step RT-PCR procedures were performed in all the experiments; first at $95{ }^{\circ} \mathrm{C}$ for $15 \mathrm{~min}$ and then 40 cycles at $95{ }^{\circ} \mathrm{C}$ for 20 $\mathrm{s}, 60^{\circ} \mathrm{C}$ for $20 \mathrm{~s}$, and $72{ }^{\circ} \mathrm{C}$ for $20 \mathrm{~s}$. A denaturation curve (melting curve) was obtained after concluding amplification at $95{ }^{\circ} \mathrm{C}$ for $15 \mathrm{~s}$ and $60{ }^{\circ} \mathrm{C}$ for $15 \mathrm{~s}$, increasing by $2{ }^{\circ} \mathrm{C} \mathrm{min}-1$ until reaching $95^{\circ} \mathrm{C}$. The combination of forward $\left(5^{\prime}\right.$ TTGCAGACCGTATGAGCAAG 3') and reverse (5'ATCCTCCGATCCAGACACTG 3') $\beta$-actin primers (10 mM) were used as a reference control. Both ges and $\beta$-actin primers amplify a $172 \mathrm{bp}$ fragment.

The graphics, Cqs, and melting curve were automatically generated by the Eco Real-Time PCR System thermocycler (Illumina) software based on the normalization method with three reference genes (Livak and Schmittgen, 2001). The expression pattern was estimated by relative quantification.

The primers used in the present study were previously designed from conserved regions of the ges gene available in the NCBI gene bank. The ClustalW2 program (www.ebi.ac.uk) was used to align the accessions (AJ457070.2) Cinnamomum tenuipilum (Yang et al., 2005), (JN408072.1) Olea europaea (Vezzaro et al., 2012), (FJ644545.1) Perilla setoyensis and (FJ644547.1) Perilla frutescens var. hirtella (Masumoto et al., 2010), (AY362553.1) O. basilicum (Iijima et al., 2004), (GU136162.1) Phyla dulcis (Yang et al., 2011), and (HM807399.1) Vitis vinifera (Martin et al., 2010).

\section{Pathogenicity test in Colletotrichum gossypii var. cephalosporioides $(\mathbf{C g c})$ isolates}

A pathogenicity assay was previously carried out to identify the most pathogenic isolates of Cgc collected from the cotton belt in the Cerrado (Savannas) region, Mato Grosso, Brazil. Five isolates were used from Pedra Preta, Primavera do Leste, Campo Verde, and Novo São Joaquim. Each isolate was cultured in potato dextrose agar (PDA) at $25^{\circ} \mathrm{C}$ and 12:12 h photoperiod for $15 \mathrm{~d}$. Conidial suspensions at $1 \times 10^{6} \mathrm{~mL}^{-1}$ were previously prepared for further inoculation of cotton plants. Seeds (cv. BRS $8 \mathrm{H})$ were sown in pots $(1 \mathrm{~L})$ containing organic substrate in a greenhouse. Two plants were maintained in each pot. At $28 \mathrm{~d}$ after emergence, leaves located at mid-canopy were superficially wounded with an abrasive solution ( $0.01 \%$; Celite 545 PA, Merck KGaA, Darmstadt, Germany) and then sprayed with a conidial suspension of each isolate. After inoculation, plants were incubated in a humid chamber for $72 \mathrm{~h}$. Each treatment (isolates) had six replicates with two plants each arranged in a completely randomized design. 
The disease severity index (DSI) was estimated $50 \mathrm{~d}$ after inoculation using a rating scale described by Lima et al. (2008): 1: plants without symptoms; 2: plants with necrosis and spots on young leaves; 3: plants with necrotic spots on leaves and stems, death of apical meristems, and shortened internodes; 4: plants with necrosis and spots on leaves and stems, shortened internodes, and excessive budding; and 5: plants showing necrotic spots on leaves, shortened internodes, excessive budding, and size reduction.

Mean results of disease ratings were calculated $78 \mathrm{~d}$ after emergence among the isolates by the formula ID $=\Sigma$ (grade scale $\times$ frequency) $\times 100$ : $\mathrm{nr}$ total unit $\times$ maximum degree of the scale; the degree of disease severity was used and estimated to describe the scale scores from 1 to 5. Data were submitted to ANOVA and means were compared by the Scott-Knot test at $5 \%$.

\section{Bioactivity of essential oils and extracts from aromatic species against Colletotrichum gossypii var. cephalosporioides (Cgc)}

This assay was performed by using the most pathogenic isolate identified in the abovementioned assay, and bioactive compounds (essential oils and crude extracts) obtained from aromatic species. Crude extracts were prepared from leaves according to the following treatments: fresh, dried $\left(37^{\circ} \mathrm{C}\right.$ for $48 \mathrm{~h}$ ), and heated (infusion at $100{ }^{\circ} \mathrm{C}$ for $10 \mathrm{~min}$ ). Each treatment was tested at $10 \%, 5 \%$, and $1 \%$.

All the treatments with essential oils were tested at 2000,1500, 1000, and $500 \mu \mathrm{L} \mathrm{L}^{-1}$ based on the methodology described by Lima et al. (2008). Oils were added separately to PDA at $50^{\circ} \mathrm{C}$ and poured onto Petri dishes $(9 \mathrm{~cm}$ diameter). A small disk $(0.5 \mathrm{~cm})$ of PDA + mycelia was deposited in the center of each plate. Plates were then randomized and incubated in a BOD (Biochemical Oxygen Demand) growth chamber at $28^{\circ} \mathrm{C}$ and $12: 12 \mathrm{~h}$ photoperiod. The diameter of the colonies was measured every $24 \mathrm{~h}$ for $7 \mathrm{~d}$. All oils used in this assay had high purity levels and were purchased commercially (www.natue.com.br).

\section{Assay validation under natural conditions}

This assay was performed by using the most responsive bioactive compounds identified in the above mentioned bioassays in curative and preventive treatments against $\mathrm{Cgc}$. Assays were conducted under field conditions from August to October

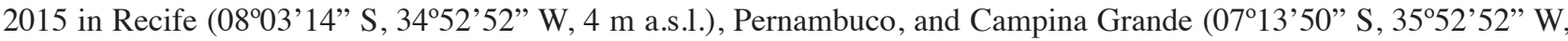
$551 \mathrm{~m}$ a.s.l.), Paraiba. Seeds of 'BRS 8H' were grown in pots $(15 \mathrm{~L})$ containing previously sterilized and fertilized soil $(\mathrm{NPK}, 30: 60: 30, \mathrm{v} / \mathrm{v})$ and watered daily. Two plants were maintained per pot. Temperature and relative humidity (RH) during the assays ranged from 29.6 to $31.2{ }^{\circ} \mathrm{C}$ and $59 \%$ to 55\%, respectively, in Recife (Apac, 2015), and 22.6 to $26.5^{\circ} \mathrm{C}$ and 57\% to 55\%, respectively, in Campina Grande (INMET, 2015).

Bioactive compounds were assayed in two treatments, that is, a curative treatment (CT) in which plants with ramulosis were further treated with bioactive compounds, and a preventive treatment (TP) in which plants previously treated with bioactive compounds were infected with $\mathrm{Cgc}$ after $24 \mathrm{~h}$. Treatments were applied at $25 \mathrm{~d}$ after emergence. Plants were sprayed with a conidial suspension $\left(1 \times 10^{6}\right)$. They were then incubated in a humid chamber for $72 \mathrm{~h}$. In the CT, a positive control was added, that is, the commercial fungicide thiophanate-methyl (dimethyl 4,4'-(o-phenylene)bis(3-

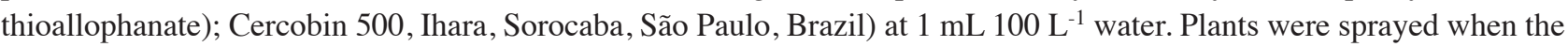
first symptoms appeared $72 \mathrm{~h}$ after inoculation.

The initial (ISI) and final severity (FSI) indices of disease were evaluated from 3 to $50 \mathrm{~d}$ after inoculation, respectively, by the formula described by Lima et al. (2008): ID $=\Sigma$ (degree of disease scale $\times$ frequency) $\times 100 /$ total number of unit $\times$ maximum degree of disease scale. The degrees of disease severity were estimated by a descriptive point scale ranging from 1 to 5 .

\section{Statistical analysis}

All assays were performed using a completely randomized design and six replicates. Data were subjected to ANOVA using Sisvar v.5.3. (Universidade Federal de Lavras, Departamento de Estatística, Lavras, Minas Gerais, Brazil). The Skott-Knott test $(p<0.05)$ was used to compare means. 


\section{RESULTS}

Eleven aromatic species (containing geraniol) were used in the present study to evaluate their effectiveness to control cotton ramulosis by focusing on molecular, phytopathological, and agronomic assays. Results showed different responses to ges expression in aromatic species and the effectiveness of essential oils to control ramulosis under natural conditions, as described below.

\section{Semiquantitative blotting and relative ges expression}

A 500 bp fragment, previously designated from geraniol synthase (ges), was used to evaluate the semiquantitative and relative expressions of the gene. The most aromatic species showed a putative ges amplicon $(0.50 \mathrm{~kb})$, which was further confirmed by RT-PCR blotting. Only M. viridis did not exhibit amplification (Figures 1A,B).

The relative expression of ges transcripts was estimated by qRT-PCR using $\beta$-actin as a reference gene. We verified several levels of expression, highlighted by M. pulegium, O. majorana, O. basilicum, and $R$. officinalis with peaks of $100 \mathrm{X}, 25 \mathrm{X}, 20 \mathrm{X}$, and 17X, respectively (Figure 2). Based on these results, these four species were selected for further in vivo and in vitro assays.

Figure 1.A: Amplicons generated by semiquantitative reverse transcription polymerase chain reaction (RT-PCR) by using ges primers; B: Blottings of ges generated by probe $(0.50 \mathrm{~kb})$ labeled with alkaline phosphatase; C: Amplicons generated by $\beta$-actin primers $(0.52 \mathrm{~kb})$ used as a reference control; M: Marker Ladder 100 bp (Ludwig); 1: Rosmarinus officinalis; 2: Ocimum gratissimum; 3: Ruta graveolens; 4: Peumus boldus; 5: Cymbopogon nardus; 6: Plectranthus amboinicus; 7: Jasminum officinale; 8: Origanum majorana; 9: Mentha spicata; 10: M. pulegium; 11: Ocimum basilicum.

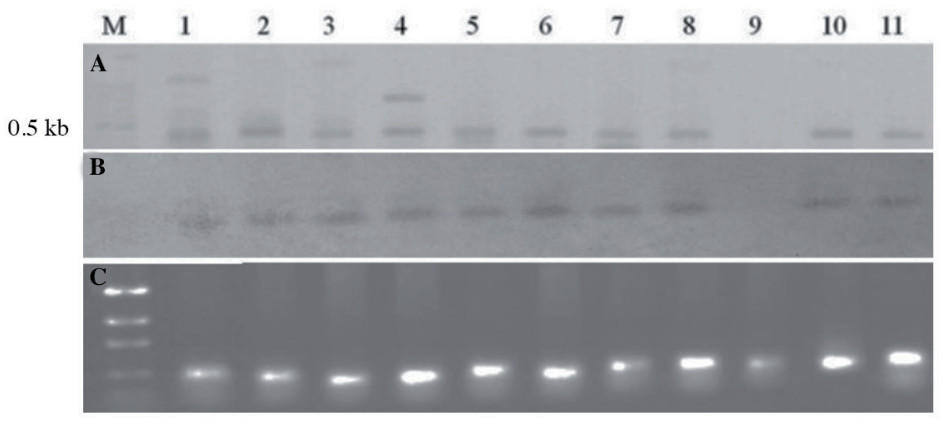

Figure 2. Relative expression of ges. Chart generated by the Eco Real-Time PCR System program (Illumina) from data $\Delta \mathrm{Cq}$ and melting curve based on the regulation of $\beta$-actin.

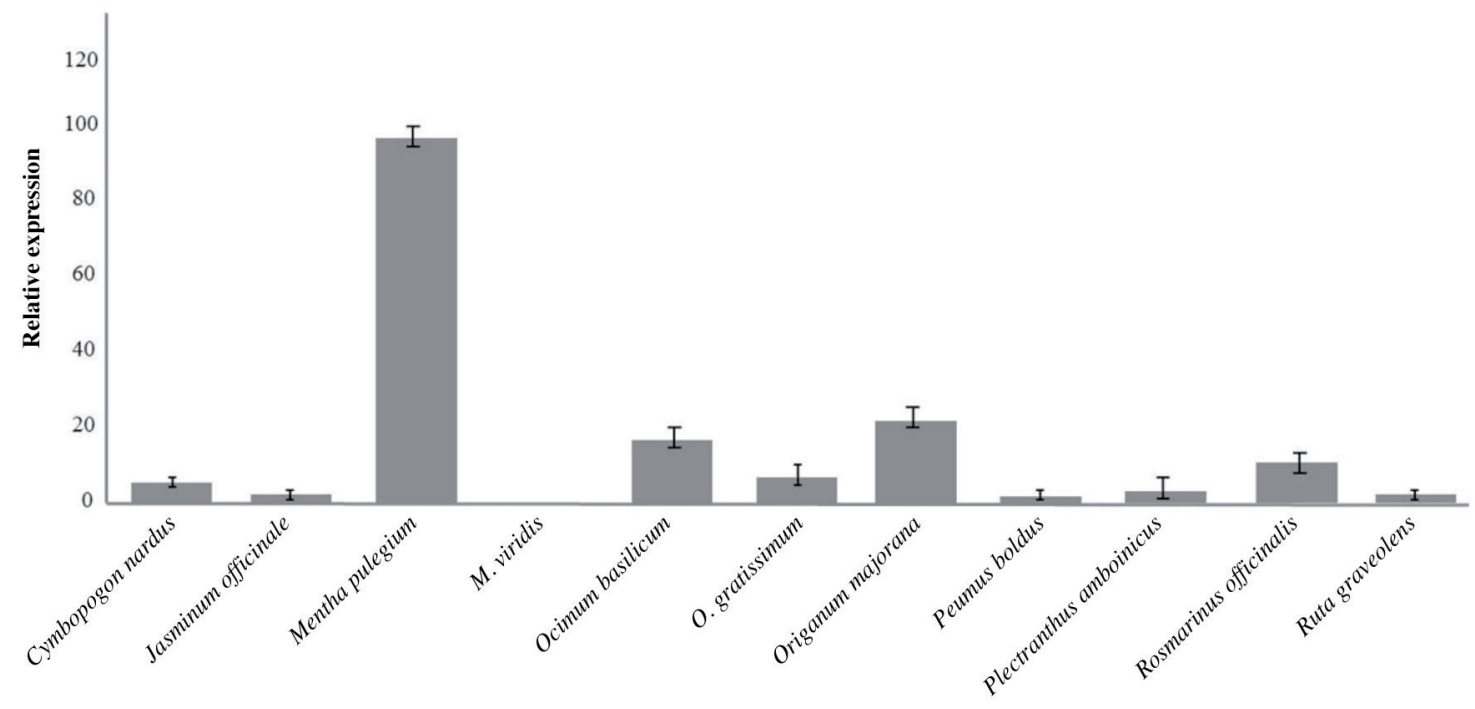


Pathogenicity of Colletotrichum gossypii var. cephalosporioides $(\mathrm{Cgc})$ isolates collected from the cotton belt in Mato Grosso

Five isolates of $C g c$ were evaluated for pathogenicity based on in vitro assays with cotton plants carried out in a greenhouse. A disease severity index (DSI) was estimated based on symptoms verified $50 \mathrm{~d}$ after inoculation. We found DSI levels ranging from $41 \%$ (CCMF-CNPA061) to 76\% (CCMF-CNPA058), as shown in Table 1. The latter was more pathogenic and was therefore selected for further assays.

\section{Phytotoxicity of selected aromatic species against Colletotrichum gossypii var. cephalosporioides (Cgc)}

Based on ges expression results obtained with molecular tools, four aromatic species were selected for phytotoxicity assays against CCMF-CNPA058-Cgc using leaf extracts and essential oils in PDA. Three concentrations of leaf extracts were tested. We found significant differences in all treatments (fresh, dried, and heated) and concentrations; however, the inhibition growth rate of CCMF-CNPA058-Cgc was quite limited, less than 50\% (Figure 3). Hence, we suggested that a possible selection of leaf extracts from M. pulegium, O. majorana, O. basilicum, or R. officinalis to control cotton ramulosis may not be viable based on the concentrations used in the present study.

We found wide differences in treatments for bioassays carried out with essential oils at low concentrations and with mycelial growth inhibition of CCMF-CNPA058-Cgc at $500 \mu \mathrm{L} \mathrm{L}^{-1}$ and full inhibition at $1500 \mu \mathrm{L} \mathrm{L}^{-1}$ (Figure 4). These are promising results because they indicate that ramulosis can be biologically controlled. The oil from M. pulegium was more effective, reducing the growth of CCMF-CNPA058-Cgc by more than $80 \%$ at $1000 \mu \mathrm{L} \mathrm{L}^{-1}$, thus confirming high expressivity (Figure 2). Details of mycelial growth in all treatments are found in Figure 5. The figure shows that the fungus was completely inhibited in the presence of M.pulegium and O. majorana at $1500 \mu \mathrm{L} \mathrm{L}^{-1}$.

\section{Field validation trials}

To confirm the results obtained with aromatic species for growth inhibition of CCMF-CNPA058-Cgc in in vitro assays (Figure 5), a trial was performed in two environments to validate the effectiveness of M. pulegium, O. majorana, and $O$. basilicum oils under natural conditions. The control of cotton ramulosis was evaluated in preventive and curative treatments using a mycelial suspension $\left(1 \times 10^{6}\right)$. The safety margin to ensure the effectiveness of the control under natural conditions was taken into account and all oils were tested at $2000 \mu \mathrm{L} \mathrm{L}^{-1}$.

Symptoms of the fungus were seen rapidly, $72 \mathrm{~h}$ after inoculation, and characterized by circular spots on young leaves and further development of star-shaped perforations in the leaf blades. At $50 \mathrm{~d}$ after inoculation, the fungus induced abnormal bud sprouting, which resulted in branch clusters.

The initial (ISI) and final severity (FSI) indices of disease in cotton plants grown in two environments are shown in Table 2. Significant differences were found in traits in both treatments for all essential oils. In the preventive treatment, we found that plants protected by M. pulegium oil showed low ISI in Campina Grande and Recife; these were the same as the values obtained with the fungicide. The mean of FSI in both environments, estimated at $50 \mathrm{~d}$ after inoculation, was $35.83 \%$ and lower than the fungicide (44.18\%). Compared to the control (plants sprayed with water and further inoculated with conidial suspension), the oil of M. pulegium reduced ISI and FSI by $42 \%$ and 50\%, respectively, in Campina Grande and $51 \%$ and $53 \%$, respectively, in Recife.

In the curative treatment, M. pulegium and $O$. basilicum oils maintained disease severity low on the scale in both environments. Compared to the control, the reduction in ISI and FSI, based on the mean of these two species, was $40 \%$

Table 1. Disease severity index (DSI) in Colletotrichum gossypii var. cephalosporioides (Cgc) isolates inoculated in cotton plants.

\begin{tabular}{|c|c|c|c|}
\hline Isolate & Location & Geographical reference & DSI $(\%)$ \\
\hline CCMF-CNPA055 & Pedra Preta/MT & $16^{\circ} 37^{\prime} 23^{\prime \prime}$ S, 542ㅇ' $26^{\prime \prime} \mathrm{W} ; 248 \mathrm{~m}$ a.s.1. & $65.20 \mathrm{~d}$ \\
\hline CCMF-CNPA058 & Primavera do Leste/MT & $15^{\circ} 33^{\prime} 32^{\prime \prime} \mathrm{S}, 54^{\circ} 17^{\prime} 46^{\prime \prime} \mathrm{W} ; 660 \mathrm{~m}$ a.s.1. & $76.00 \mathrm{e}$ \\
\hline CCMF-CNPA060 & Campo Verde/MT & $15^{\circ} 32^{\prime} 48^{\prime \prime} \mathrm{S}, 55^{\circ} 10^{\prime} 08^{\prime \prime} \mathrm{W} ; 736 \mathrm{~m}$ a.s.l. & $58.40 \mathrm{c}$ \\
\hline CCMF-CNPA061 & Primavera do Leste/MT & $15^{\circ} 33^{\prime} 32^{\prime \prime}$ S, 54 $4^{\circ} 17^{\prime} 46^{\prime \prime}$ W; $660 \mathrm{~m}$ a.s.l. & $40.20 \mathrm{a}$ \\
\hline CCMF-CNPA065 & Novo São Joaquim/MT & $14^{\circ} 54^{\prime} 21^{\prime \prime} \mathrm{S}, 53^{\circ} 01^{\prime} 06^{\prime \prime} \mathrm{W} ; 400 \mathrm{~m}$ a.s.1. & $49.80 \mathrm{~b}$ \\
\hline $\mathrm{CV} \%$ & & & 3.48 \\
\hline
\end{tabular}

Means followed by the same letter do nonsignificantly differ according to the Scott-Knott test ( $\mathrm{p} \leq 0.05)$. 
Figure 3. Inhibition rate of CCMF-CNPA058-Cgc growth in potato dextrose agar (PDA) containing leaf extracts A: heated (infusion at $100{ }^{\circ} \mathrm{C}$ for $\left.10 \mathrm{~min}\right)$; B: fresh; C: dried $\left(37^{\circ} \mathrm{C}\right.$ for $\left.48 \mathrm{~h}\right)$. $\bullet$ Ocimum basilicum; + Mentha pulegium; n Rosmarinus officinalis; $\Delta$ Origanum majorana. Regression equation and $\mathbf{R}^{2}$ are shown for each sample. Coefficient of variation $(\mathrm{CV} \%)$ and $F$ values for treatments $A: 1.40$ and 117.77; B: 0.88 and 857.70; C: 1.52 and 181.36, respectively.
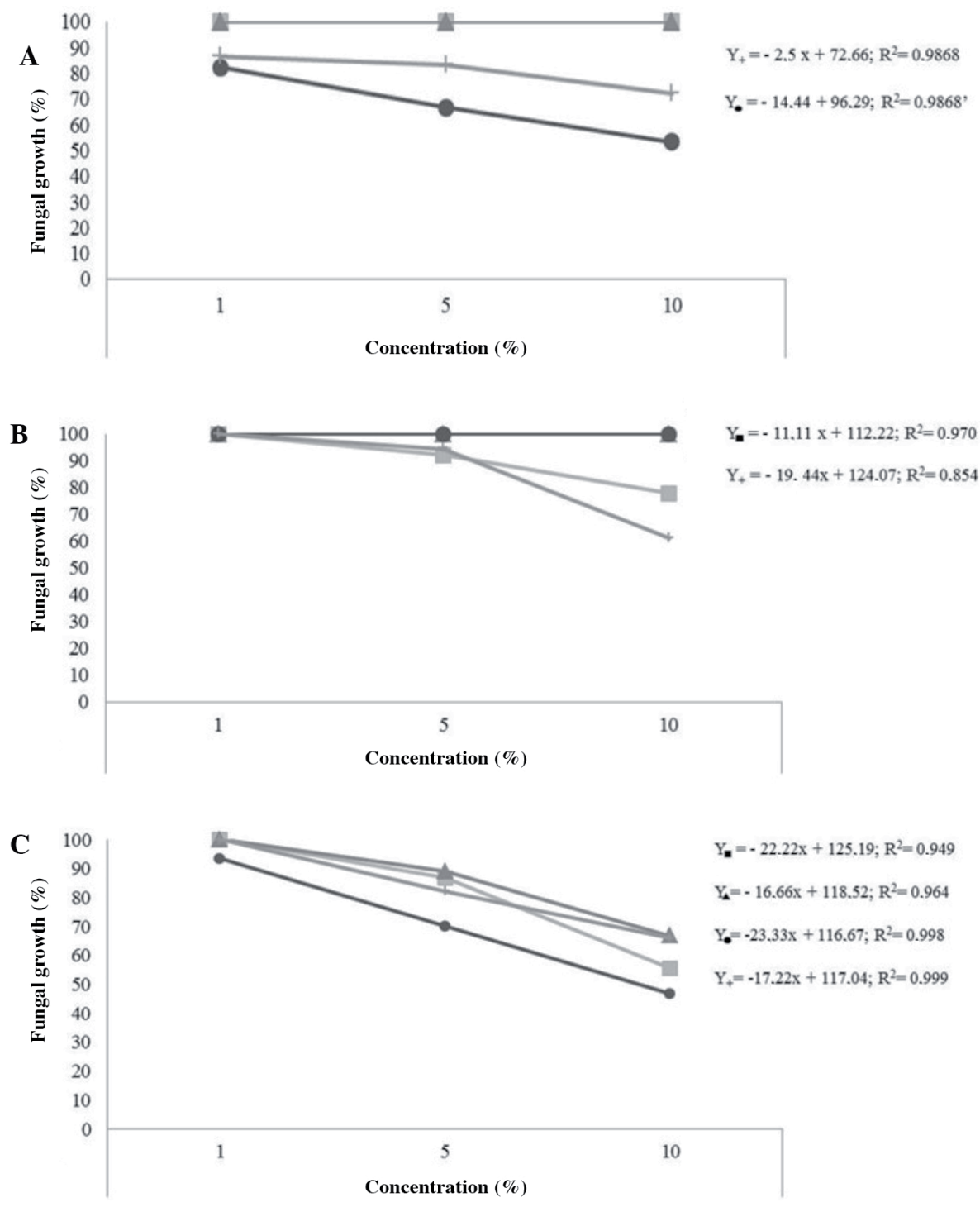

and 55\%, respectively, in Campina Grande and 47\% and 53\%, respectively, in Recife respectively. These results are closer to those found in the preventive treatment. The performance of cotton plants protected with M. pulegium in preventive and curative treatments in two environments is revealed in Figure 6. In both situations, the canopy of plants treated with oil was healthier and more vigorous when compared to both the control and the fungicide treatment.

\section{DISCUSSION}

Crop pests are the main obstacles to productivity and agricultural growth. Despite the various strategies currently available to combat them, synthetic pesticides are the most used and these increase production costs and environmental damage.

Society is demanding that technologies be developed which are less aggressive to man and are more agroecological; this has stimulated studies related to protecting plants with plant bioactive compounds. In countries with extensive biodiversity, such as Brazil, investment in research in this segment generally provides promising results. 
Figure 4. Inhibition rate of CCMF-CNPA058-Cgc growth in potato dextrose agar (PDA) containing essential oil of aromatic species. - Ocimum basilicum L.; + Mentha pulegium; - Rosmarinus officinalis; $\Delta$ Origanum majorana. Regression equation and $R^{2}$ are shown for each sample. Coefficient of variation: 4.47; $F$ value: 361.40 .

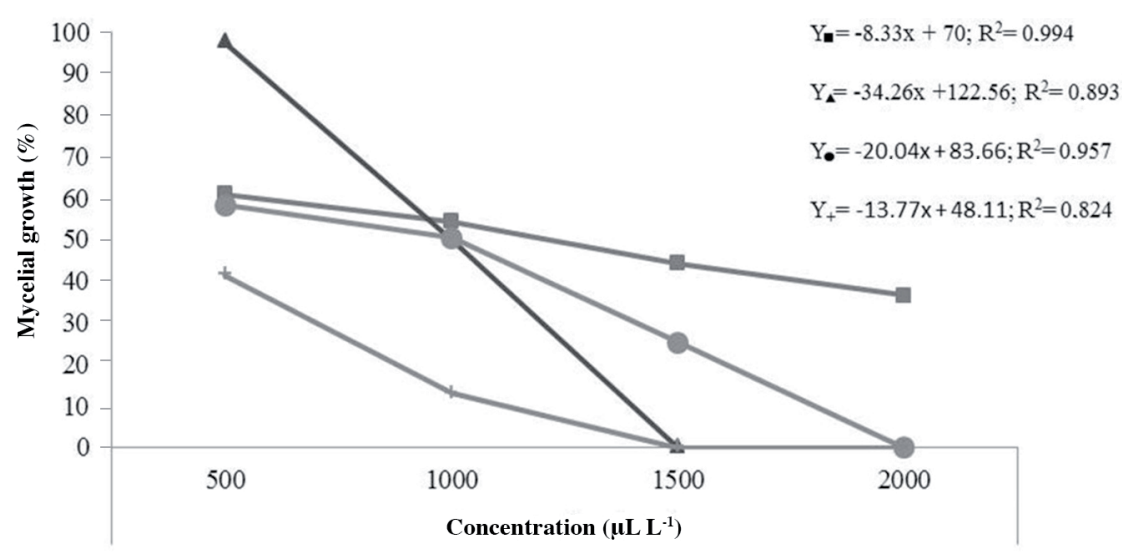

Figure 5. Details of CCMF-CNPA058-Cgc growth in potato dextrose agar (PDA) containing essential oil of aromatic species. A: Rosmarinus officinalis; B: Origanum majorana; C: Ocimum basilicum; D: Mentha pulegium; 1: Control; 2: 500 $\mu \mathrm{L} \mathrm{L}^{-1} ; 3: 1000 \mu \mathrm{L} \mathrm{L}^{-1} ; 4: 1500 \mu \mathrm{L} \mathrm{L}^{-1} ; 5: 2000 \mu \mathrm{L} \mathrm{L}^{-1}$.

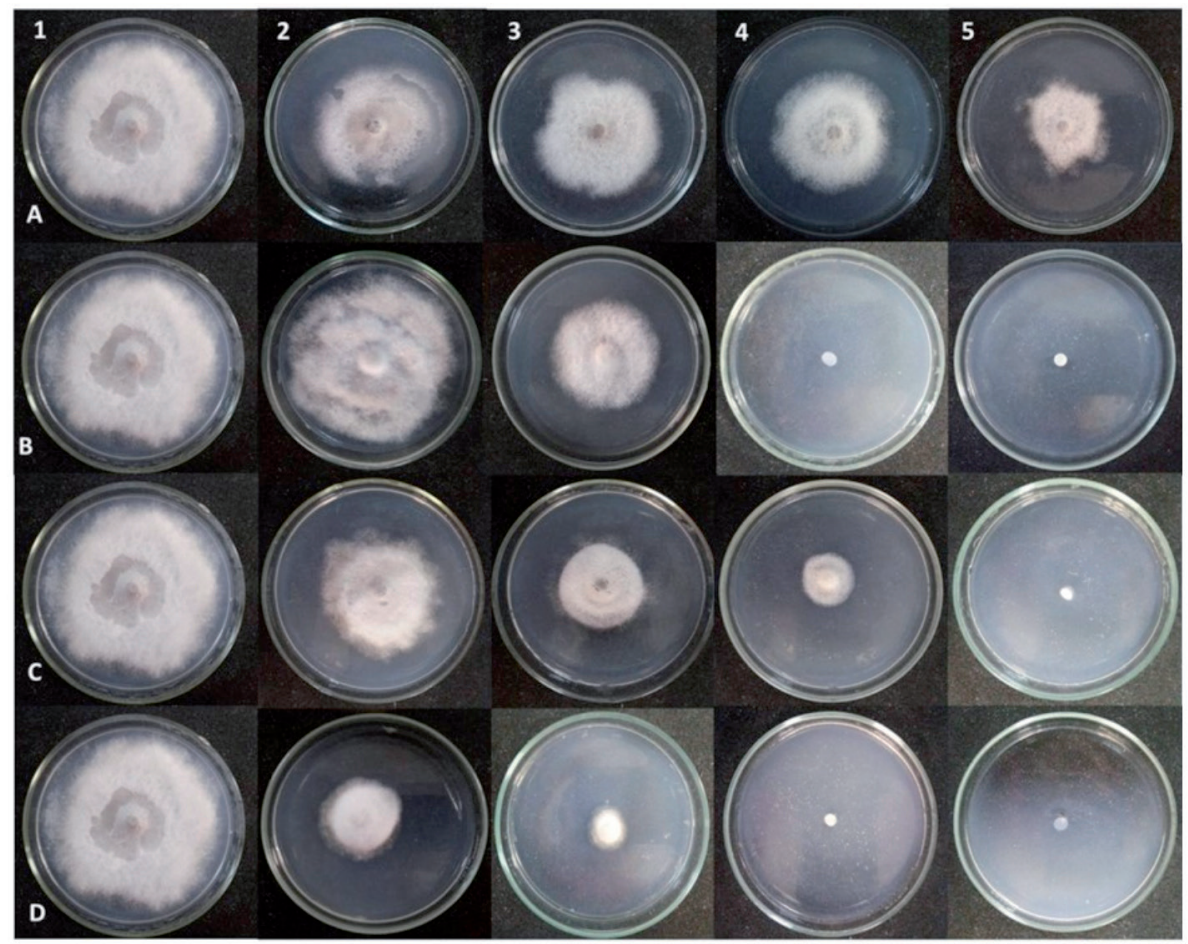

Despite the large number of articles available in the literature that demonstrate the potential of some plant bioactive compounds for crop protection, some of them are limited to in vitro assays, whose results are not always confirmed when used under natural conditions. We used various tools to prove the effectiveness of aromatic species to control cotton ramulosis.

First, we made a botanic query about aromatic species that putatively contain geraniol, based on the characteristic aroma exhaled in leaves. Since the level of geraniol is variable between species and a limitation to quantify this terpenoid by chromatography, the strategy to identify promising species through the expression of ges transcripts was appropriate because the gene encodes geraniol synthase, a precursor enzyme in the biosynthetic chain of geraniol (Masumoto et al., 2010; Vezzaro et al., 2012; Simkin et al., 2013). 
Table 2. Initial severity (IIS) and final severity (IFS) indices of disease in cotton plants inoculated with CCMF-CNPA058-Cgc in preventive and curative treatments with essential oils.

\begin{tabular}{|c|c|c|c|c|c|c|c|c|}
\hline \multirow{3}{*}{$\begin{array}{l}\text { Essential } \\
\text { oil }\end{array}$} & \multicolumn{4}{|c|}{ Preventive } & \multicolumn{4}{|c|}{ Curative } \\
\hline & \multicolumn{2}{|c|}{ CG } & \multicolumn{2}{|c|}{ REC } & \multicolumn{2}{|c|}{ CG } & \multicolumn{2}{|c|}{ REC } \\
\hline & IIS & IFS & IIS & IFS & IIS & IFS & IIS & IFS \\
\hline & & & & & & & & - \\
\hline 1 & $19.32 \mathrm{~b}$ & $51.66 \mathrm{~b}$ & $17.59 \mathrm{~b}$ & $53.33 \mathrm{~b}$ & $21.04 \mathrm{~b}$ & $36.67 \mathrm{a}$ & $14.14 \mathrm{a}$ & $35.00 \mathrm{a}$ \\
\hline 2 & $14.14 \mathrm{a}$ & $38.33 \mathrm{a}$ & $14.14 \mathrm{a}$ & $33.33 \mathrm{a}$ & $14.14 \mathrm{a}$ & $31.66 \mathrm{a}$ & $14.14 \mathrm{a}$ & $31.66 \mathrm{a}$ \\
\hline 3 & $24.49 \mathrm{c}$ & $63.33 \mathrm{c}$ & $19.31 \mathrm{~b}$ & $60.00 \mathrm{~b}$ & $14.14 \mathrm{a}$ & $46.67 \mathrm{~b}$ & $22.77 b$ & $55.00 \mathrm{~b}$ \\
\hline 4 & $24.49 \mathrm{c}$ & $76.67 \mathrm{~d}$ & $26.87 \mathrm{c}$ & $71.67 \mathrm{c}$ & $26.87 \mathrm{c}$ & $76.67 \mathrm{c}$ & $26.87 \mathrm{c}$ & $71.67 \mathrm{c}$ \\
\hline 5 & $14.14 \mathrm{a}$ & $46.67 \mathrm{~b}$ & $14.14 \mathrm{a}$ & $41.67 \mathrm{a}$ & - & - & - & - \\
\hline CV \% & 15.88 & 6.19 & 15.88 & 6.19 & 16.29 & 5.51 & 16.29 & 5.51 \\
\hline
\end{tabular}

Means with the same letter do nonsignificantly differ according to the Scott-Knott test $(\mathrm{p}<0.05)$. Original data transformed by $\sqrt{ }(\mathrm{x}+0.5)$ for statistical analysis.

1: Ocimum basilicum; 2: Mentha pulegium; 3: Origanum majorana; 4: Control (plants inoculated with fungus and sprayed with distilled water); 5: Fungicide (thiophanate-methyl).

CG: Campina Grande; REC: Recife; CV: coefficient of variation.

Preventive: plants were previously treated with essential oil or fungicide and infected with fungus after $24 \mathrm{~h}$; Control in curative treatment: Plants infested with ramulosis were further treated with distilled water; Control in preventive treatment: plants previously treated with distilled water were then infected with fungus after $24 \mathrm{~h}$; Curative: plants infested with ramulosis were further treated with essential oil.

Figure 6. Performance of cotton plants ('BRS 8H') subjected to inoculation with CCMF-CNPA058-Cgc in preventive and curative treatments with Mentha pulegium oil in Recife (left) and Campina Grande (right). A and $\mathrm{E}$ : curative, $\mathrm{B}$ and $\mathrm{F}$ : preventive, $\mathrm{C}$ and $\mathrm{G}$ : fungicide, $\mathrm{D}$ and $\mathrm{H}$ : control treatments.
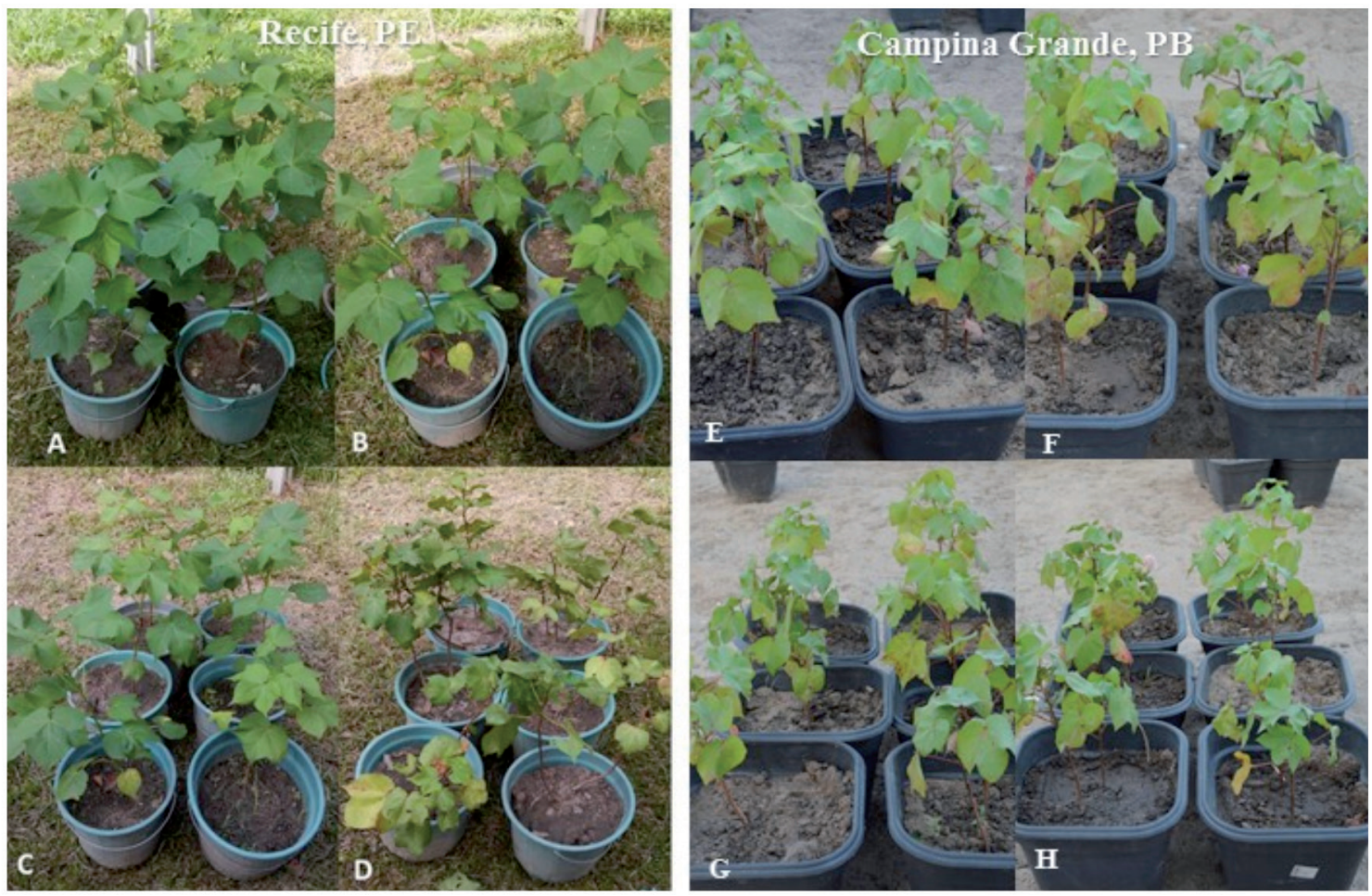

The relative expression of M. pulegium was higher than other accessions (Figure 1). Unaware of the biochemical characteristics of the extract and essential oil of aromatic species under natural conditions, we decided to include three other accessions in additional assays (R. officinalis, O. majorana, and $O$. basilicum) because they also showed a reasonable expression of ges transcripts. 
Another strategy was to perform in vivo assays in different environments to demonstrate the effectiveness of the oils used; both locations provided favorable environmental conditions for disease development and validation of results. According to Carvalho et al. (1981), the analysis of several isolates of C. gossypii var. cephalosporioides cotton collected in the region of Goiás in Brazil has shown that the best temperature for fungal growth is $28{ }^{\circ} \mathrm{C}$ and that growth is markedly reduced below $15^{\circ} \mathrm{C}$ and above $33^{\circ} \mathrm{C}$.

Based on the methodologies and species implemented in the present study, no expressive effect was found with leaf extracts to control cotton ramulosis in in vitro assays (Figure 3), although some results have been found in the literature with others pathogens or crops at high concentration of extracts in in vitro assays. Celoto et al. (2011) used leaf and branch extracts from Momordica charantia at 50\% and found inhibition of 71\% and 65\% in mycelial growth, respectively, in a solid medium; the inhibitions in the liquid medium were $86 \%$ and $81 \%$, respectively. Venturoso et al. (2011) found that extracts of Syzygium aromaticum (L.) Merr. \& L.M. Perry, Allium sativum L., and Cinnamomum zeylanicum Blume at $20 \%$ reduced the mycelial growth of several pathogens, including Colletotrichum sp. and Fusarium solani. Although these findings are interesting, the feasibility for further implementation may be limited by the great amount of raw material necessary to prepare the extract. Our results with essential oils showed that the best was M.pulegium, which inhibited fungal growth at $1000 \mu \mathrm{L} \mathrm{L}^{-1}$ in an in vitro assay (Figure 4). Furthermore, in validation tests with cotton plants infected with Cgc, M. pulegium oil at $2000 \mu \mathrm{L} \mathrm{L}^{-1}$ reduced the initial and final severity of disease indices to $48 \%$ and $52 \%$, respectively, in the preventive treatment, while it was $44 \%$ and $54 \%$, respectively, in the curative assays based on the means of two environments (Table 2). These results are quite expressive because they demonstrate viability to control cotton ramulosis by natural bioactive compounds.

Mentha pulegium is a perennial runner plant, belonging to the Lamiaceae family; it is native to Europe and North Africa as well as Asia and the Middle East (Oliveira et al., 2011; Wang et al., 2013). The Mentha genus has several species known as mints and is widely distributed worldwide mainly in tropical and subtropical regions (Toloza et al., 2006; Wang et al., 2013). The attractive characteristic aroma is exhaled from the whole plant, especially in its aerial parts that have glandular trichomes that are responsible for biosynthesis and essential oil secretion (Rodrigues et al., 2013). Mentha pulegium oil is primarily a compound of oxygenated monoterpenes, including geraniol (Karray-Bouraoui et al., 2009; Teixeira et al., 2012). However, menthol is one of the main oil components (Darvishi et al., 2016).

Considering the ease of management and wide climatic adaptability of the species, the cultivation of mint could be incorporated on farms to further implement the natural control of cotton ramulosis in agroecological management.

\section{CONCLUSIONS}

Mentha pulegium reduced the initial and final severity indices of the disease in the preventive treatment and curative assays, indicating that it is a promising bioactive compound to control cotton ramulosis. The use of oils and extracts may prove to be an effective and sustainable alternative for the treatment of ramulosis. Furthermore, the genetic characterization of aromatic species constitutes an important source of information for using natural resources, enabling the discovery of new species possessing genes responsible for the synthesis of metabolites that serve as an alternative for environmental conservation strategies.

\section{ACKNOWLEDGEMENTS}

We thank the Empresa Brasileira de Pesquisa Agropecuária (Embrapa) and Coordenação de Aperfeiçoamento de Pessoal de Nível Superior (CAPES) for financial support and scholarship funding.

\section{REFERENCES}

Anvisa. 2014. Programa de análise de resíduos de agrotóxicos em alimentos. Agência Nacional de Vigilância Sanitária (ANVISA), Brasília, Brazil. Available at http://www.anvisa.gov.br (accessed July 2015).

Apac. 2015. Informe climático de setembro de 2015. Agência Pernambucana de Águas e Clima (APAC), Recife, Pernambuco, Brasil. Available at http://www.apac.pe.gov.br/arquivos_portal/informes/Informe_Climatico_Setembro_2015.pdf (accessed June 2016). 
Carvalho, L.P., Carvalho, J.M.F.C., Lima, E.F., e Cavalcante, F.B. 1981. Influência da concentração de esporos na patogenicidade de Colletotrichum gossypii South var. cephalosporioides A.S. Costa e avaliação da resistência de cultivares e linhagens de algodoeiro herbáceo à ramulose. Fitopatologia Brasileira 6:395-402.

Celoto, M.I.B., Papa, M.F.S., Sacramento, L.V.S., and Celoto, F.J. 2011. Antifungal activity of Momordica charantia L. extracts on Colletotrichum musae. Journal Medicinal Plants 13:337-341.

Conab. 2016. Monitoramento agrícola - Cultivos de inverno (safra 2015) e de verão (safra 2015/16). Companhia Nacional de Abastecimento (Conab), Brasília DF, Brasil. Available at http://www.conab.gov.br (accessed January 2016).

Darvishi,E., Kahrizi, D., Bahraminejad, S., and Mansouri, M. 2016. In vitro induction of $\alpha$-pinene, pulegone, menthol, menthone and limonene in cell suspension culture of pennyroyal (Mentha pulegium). Cell Molecular Biology 3:7-9.

Guerra, Y.L., Oliveira, T.A.S., Laranjeira, D., Lima, L.M., Melo-Filho, P.A., and Santos, R.C. 2015. Control of Sclerotium rolfsii in peanut by using Cymbopogon martinii essential oil. African Journal of Microbiology Research 9:1684-1691.

Hussain, A.I., Anwar, F., Sherazi, S.T.H., and PrzybylskI, R. 2008. Chemical composition, antioxidant and antimicrobial activities of basil (Ocimum basilicum) essential oils depends on seasonal variations. Food Chemistry 108:986-995.

Iijima, Y., Gang, D.R., Fridman, E., Lewinsohn, E., and Pichersky, E. 2004. Characterization of geraniol synthase from the peltate glands of sweet basil. Plant Physiology 134:370-379.

INMET. 2015. Estação meteorológica de observação de superfície automática. Instituto Nacional de Meteorologia (INMET), Brasília-DF, Brasil.Available at http://www.inmet.gov.br/portal/index.php?r=estacoes/estacoesautomaticas (accessed June 2015).

Karray-Bouraoui, N., Rabhi, M., Neffati, M., Baldan, B., Ranieri, A., Marzouk, B., et al. 2009. Salt effect on yield and composition of shoot essential oil and trichome morphology and density on leaves of Mentha pulegium. Industrial Crops and Products 30:338-343.

Lima, W.G., Santos, R.C., Câmara, C.A.G., Câmara, M.P.S., and Melo-Filho, P.A. 2008. Citronella oil inhibits cotton ramulosis in controlled conditions. Pest Technology 2:24-27.

Livak, K.J., and Schmittgen, T.D. 2001. Analysis of relative gene expression data using real time quantitative PCR and the 2- $\Delta \Delta C \mathrm{CT}$ method. Methods 25:402-408.

Martin, D.M., Aubourg, S., Schouwey, M.B., Daviet, L., Schalk, M., Toub, O., et al. 2010. Functional annotation, genome organization and phylogeny of the grapevine (Vitis vinifera) terpene synthase gene family based on genome assembly, FLcDNA cloning, and enzyme assays. Plant Biology 10:2-22.

Masumoto, N., Korin, M., and Ito, M. 2010. Geraniol and linalool synthases from wild species of perilla. Phytochemical 71:1068-1075.

Melo, R.M.C.A., Melo-Filho, P.A., Câmara, M.P.S., Lima, W.G., and Santos, R.C. 2013. Preventive control of cotton ramulosis using clove oil at low concentration. International Journal of Agricultural Science and Research 2:060-066.

O'Bryan, C.A., Pendleton, S.J., Crandall, P.G., and Ricke, S.C. 2015. Potential of plant essential oils and their components in animal agriculture - in vitro studies on antibacterial mode of action. Frontiers in Veterinary Science 2:1-8.

Oliveira, R.A., Sa, I.C.G., Duarte, L.P., e Oliveira, F.F. 2011. Constituintes voláteis de Mentha pulegium L. e Plectranthus amboinicus (Lour.) Spreng. Revista Brasileira de Plantas Medicinais 13:165-169.

Pignati, W., Oliveira, N.P., e Silva, A.M.C. 2014. Vigilância aos agrotóxicos: quantificação do uso e previsão de impactos na saúde-trabalho-ambiente para os municípios brasileiros. Ciência e Saúde Coletiva 19:4669-4678.

Rodrigues, L., Póvoa, O., Teixeira, G., Figueiredo, A.C., Moldão, M., and Monteiro, A. 2013. Trichomes micromorphology and essential oil variation at different developmental stages of cultivated and wild growing Mentha pulegium L. populations from Portugal. Industrial Crops and Products 43:692-700.

Rozwalka, L.C., Lima, M.L.R.Z.C., Mio, L.L.M., e Nakashima, T. 2008. Extratos, decoctos e óleos essenciais de plantas medicinais e aromáticas na inibição de Glomerella cingulata e Colletotrichum gloeosporioides de frutos de goiaba. Rural Science 38:301-307

Santos, B.T., Bonaldo, S.M., and Schwan-Estrada, K.R.F. 2011. Essential oils of forest and medicinal species in the control ramulosis (Colletotrichum gossypii var. cephalosporioides) cotton. Agroecology Books 6:2236-7934.

Simkin, A.J., Miettinen, K., Claude, L.P., Burlat, V., Guirimand, G., Courdavaul, T.V., et al. 2013. Characterization of the plastidial geraniol synthase from Madagascar periwinkle which initiates the monoterpenoid branch of the alkaloid pathway in internal phloem associated parenchyma. Phytochemistry 85:36-43.

Singh, N., Wang, C., and Cooper, R. 2014. Potential of essential oil-based pesticides and detergents for bed bug control. Encontro de Entomologia 107:1-8.

Soares, T.C., Silva, C.R.C., Carvalho, J.M.F.C., Cavalcanti, J.J.V., Lima, L.M., Melo Filho, P.A., et al. 2018. Validating a probe from GhSERK1 gene for selection of cotton genotypes with somatic embryogenic capacity. Journal of Biotechnology 270:44-50.

Sousa Júnior, I.T.S., Sales, N.L.P., e Martins, E.R. 2009. Efeito fungitóxico de óleos essenciais sobre Colletotrichum gloeosporioides, isolado do maracujazeiro amarelo. Revista Biotemas 22:77-83.

Suassuna, N.D., e Coutinho, W.M. 2015. Manejo das principais doenças do algodoeiro no cerrado brasileiro. p. 365-407. In Freire, E.C.Algodão no Cerrado do Brasil. 3 ed. Gráfica e Editora Positiva, Brasília, Brasil. 
Teixeira, B., Marquesa, A., Ramosa, C., Batista, I., Serrano, C., Matos, O., et al. 2012. European pennyroyal (Mentha pulegium) from Portugal: chemical composition of essential oil and antioxidant and antimicrobial properties of extracts and essential oil. Industrial Crops and Products 36:81-87.

Toloza, A.C., Zygadlo, J., Mougabure Cueto, G., Biurrun, F., Zerba, E., and Picollo, M.I. 2006. Fumigant and repellent properties of essential oils and component compounds against permethrin-resistant Pediculus humanus capitis (Anoplura: Pediculidae). Journal of Medical Entomology 43:889-895.

Venturoso, L.R., Bacchi, L.M.A., Gavasson, I.W.L., Conus, L.A., Pontim, B.C.A., e Bergamin, A.C. 2011 . Atividade antifúngica de extratos vegetais sobre o desenvolvimento de fitopatógenos. Summa Phytopathologica 37:18-23.

Vezzaro, A., Krause, S.T., Nonis, A., Ramina, A., Degenhardt, J., and Ruperti, B. 2012. Isolation and characterization of terpene synthases potentially involved in flavor development of ripening olive (Olea europaea) fruits. Journal of Plant Physiology 169:908-914.

Wang, H.T., Yu, X., Liu, Y., Liang, C.Y., and Li, W.L. 2013. Analysis of genetic variability and relationships among Mentha L. using the limonene synthase gene, LS. Gene 524:246-252.

Yang, T., Li, J., Wang, H.X., and Zenga, Y. 2005. A geraniol-synthase gene from Cinnamomum tenuipilum. Phytochemistry 66:285-293.

Yang, T., Stoopen, G., Yalpani, N., Vervoort, J., de Vos, R., Voster, A., et al. 2011. Metabolic engineering of geranic acid in maize to achieve fungal resistance is compromised by novel glycosylation patterns. Metabolic Engineering 13:414-425. 